\title{
Building a global platform for organic farming research, innovation and technology transfer
}

\author{
Urs Niggli • Christian Andres $(\mathbb{D} \cdot$ Helga Willer • \\ Brian P. Baker
}

Received: 30 May 2017 / Accepted: 1 August 2017

(C) Springer Science+Business Media B.V. 2017

\begin{abstract}
Organic food and farming systems have a great untapped potential to provide the world with healthy, high-quality food that is produced and distributed in an ecologically sound and fair way, but numerous production challenges and barriers slow the adoption of organic practices. Innovations addressing these challenges are not being developed sufficiently because of insufficient capacity in research, development and technology transfer, especially in Africa, Asia and Latin America. Given the limited resources, as well as the specific needs of organic food and farming systems, different pathways are needed to develop new technologies that are compatible with the principles of organic farming. The Technology Innovation Platform of IFOAM - Organics International (TIPI) was established to advance organic farming through research, development, innovation and technology transfer. As a global platform for organic food and farming systems research, innovation and technology transfer, TIPI advocates for
\end{abstract}

U. Niggli $\cdot$ C. Andres $(\bowtie) \cdot H$. Willer $(\bowtie)$

Research Institute of Organic Agriculture (FiBL), Ackerstrasse

113, Postfach 219, 5070 Frick, Switzerland

e-mail: christian.andres@fibl.org

e-mail: helga.willer@ fibl.org

C. Andres

Department of Environmental Systems Science, Swiss Federal Institute of Technology, ETH Zurich, Tannenstrasse 1,

8092 Zurich, Switzerland

B. P. Baker

Belcairn Concerns, PO Box 12256, Eugene, OR 97440, USA three main pathways along which this is expected to happen, each of which comes with a specific set of research objectives and outcomes: (1) empower rural areas, (2) practice eco-functional intensification and (3) produce food for health and well-being. TIPI identified three strategies to build the necessary capacity: (1) develop research methods appropriate for organic food and farming systems; (2) renew partnerships between farmers, farm advisors, scientists and consumers; and (3) integrate technological, social and ecological dimensions of innovation.

Keywords Organic farming · Sustainable intensification · Research · Innovation development . Technology transfer

\section{Introduction}

Organic farming offers the promise of a world where food and other farm products are produced and distributed in a healthy, ecologically sound, sustainable and fair way (IFOAM 2005). This promise, however, is not realized because of various obstacles and challenges. The opportunity for organic farming to grow and prosper is impeded by technological barriers, policies that favour the continued use of chemical fertilizers, pesticides and animal medicine, as well as by an economic system where the price of food does not reflect the full costs of the environmental and social consequences of its production (El-Hage Scialabba and Hattam 2002; 
Jerkins and Ory 2016; Niggli 2008, 2015; Rahmann et al. 2009; Reganold and Wachter 2016).

Intending to advance organic farming through research, development, innovation and technology transfer, IFOAM - Organics International, an international non-governmental organization that serves as a global umbrella group for the organic movement, established the Technology Innovation Platform of IFOAM-Organics International (TIPI). As a global platform for organic food and farming systems research, innovation and technology transfer, TIPI aims to bridge the gap not only between the researchers and the beneficiaries of research - particularly farmers - but also other practitioners that span the entire value chain all the way to the final consumers all over the world. Since its launch in 2013, TIPI has engaged and involved stakeholders that benefit from organic food and farming systems research to develop a global agenda and advocate for the priority of its funding (Niggli et al. 2016). This paper briefly summarizes the benefits of organic farming, the challenges there are for organic farming to feed a growing world population and the current capacity of organic farming research to address these challenges. The authors then describe different pathways TIPI has elaborated to develop new technologies compatible with the principles of organic farming. The article concludes with a strategy to advance organic farming through research, development, innovation and technology transfer.

\section{Benefits and challenges of organic food and farming systems}

Empirical evidence not only supports the benefits and strengths of organic food and farming systems but also highlights challenges and opportunities for their improvement. Soil quality and health can be improved by organic farming practices, as measured by soil fertility and structure and by biodiversity of soil organisms (Fließbach et al. 2007; Mäder et al. 2002; Marriott and Wander 2006; Pulleman et al. 2003; Reganold et al. 2001). Organic farming maintains and increases soil organic matter, sequesters carbon and reduces greenhouse gas emissions relative to other forms of agriculture (Gadermaier et al. 2011; Gattinger et al. 2012; Skinner et al. 2014). Furthermore, soil erosion is less likely in organic soils in the long run (Reganold et al. 1987; Siegrist et al. 1998), and increased biological activity in the soil helps to both suppress pests and diseases and enhance plant immunity to various opportunistic infections (Altieri et al. 2005). Organic farming has higher nutrient efficiencies by relying on the cycling of nutrients from renewable resources, mainly in the form of organic matter, rather than on synthetic fertilizers that are derived from non-renewable resources (Drinkwater et al. 1998; Kramer et al. 2006; Reganold and Wachter 2016).

On average, organic farming systems have lower yields than conventional farming systems (de Ponti et al. 2012; Seufert et al. 2012). Thus, more land may be needed to produce the same amount of food using organic practices, which may diminish the ecological and health benefits of organic relative to conventional farming when measured on a production unit basis (Seufert and Ramankutty 2017). However, the greater biodiversity of organic food and farming systems through cultural practices such as crop rotations, interand relay-cropping may offset yield gaps (Ponisio et al. 2015). Yields in organic farming systems may also be more stable under environmental stress and adverse weather conditions than in conventional farming systems (Eyhorn et al. 2007; Lotter et al. 2003).

Organic farming is generally more profitable to farmers, particularly when they receive a price premium for their products (Crowder and Reganold 2015; Mahoney et al. 2007; Reganold et al. 1993). Yield and gross returns can vary by crop, but the gross margin (after subtraction of production costs) may partially offset yield reductions in the long run (Forster et al. 2013). At least in some cases, organic food and farming systems may also have higher returns to labour (Armengot et al. 2016). However, without a premium or with low premiums, organic farming systems can be less profitable, in part because of lower yields (Crowder and Reganold 2015; McBride et al. 2015). The organic sector's small market share accounts for about $1 \%$ of global food sales (Willer and Lernoud 2017), which is probably the single most limiting factor for farmers to adopt organic practices. Organic farming also contributes to "triple bottom line" accounting for social and economic, as well as environmental benefits through multiple functions (Schader et al. 2013).

Organic farming systems have been shown to enhance the resilience of agroecosystems by increasing natural pest control and enhancing biodiversity in the soil, as well as at the plot, farm and landscape scale (Bengtsson et al. 2005; Frieben and Köpke 1995; Fuller 
et al. 2005; Hole et al. 2005; Mulder et al. 2003; Rahmann 2011; Tuck et al. 2014; Vandermeer et al. 2010). Furthermore, organic farming systems increase populations of pollinators and other beneficial organisms (Andersson et al. 2012; Gabriel et al. 2006; Holzschuh et al. 2007; Kragten and de Snoo 2008; Kragten et al. 2008; Pfiffner et al. 2003; Rundlöf et al. 2008; Wickramasinghe et al. 2003; Wilson et al. 1997).

Organic farming systems also provide environmental benefits across multiple physical, chemical, biological, economic and social parameters (Schader et al. 2012, 2013; Stolze et al. 2000). Life cycle assessments (LCAs) have compared the relative environmental performance of certain aspects of organic and conventional farming, focusing on the inputs used by the different systems (Meier et al. 2015). However, LCAs have methodological shortcomings, as they have not been able to fully capture the environmental and social benefits reflected in ecosystem services and the market, respectively (Meier et al. 2015). The economic and environmental values of the biodiversity conserved by organic farming systems are difficult to estimate given the qualitative differences between extensive organic and intensive conventional productions (TEEB 2010). Given that organic farming systems require more land to produce the same amount of food, they would theoretically lead to less land being available for unfarmed wildlife habitats (Seufert and Ramankutty 2017). In practice, however, the choices and outcomes are more complex. Land sparing and wildlife friendly agriculture can be complementary rather than mutually exclusive (Fischer et al. 2008).

Because most pesticides are not permitted in organic food, they are less likely to have pesticide residues, far less likely to have multiple residues and-when contaminated by drift, persistent pollutants, or ambient conditions - have significantly lower levels of pesticides than other food (Baker et al. 2002). As a result, organic foods pose lower dietary risks from pesticides to human health than conventional foods (Benbrook and Baker 2014). Moreover, pesticide risks to the environment are also mitigated by organic production practices (Gomiero et al. 2011; Pimentel et al. 2005). Organic food also has lower levels of cadmium, nitrate and nitrite compared to conventionally produced food (Barański et al. 2014; Średnicka-Tober et al. 2016a).

Meta-analyses about the nutritional quality of organic food have shown mixed results. Some studies concluded that there is no nutritional difference between organic and conventional foods (Dangour et al. 2010; SmithSpangler et al. 2012), while others have found that organic food has significantly greater density of certain nutrients (Barański et al. 2014; Benbrook et al. 2013; Brandt et al. 2011; Średnicka-Tober et al. 2016a, b).

Organic farming is not mainstream (Willer and Lernoud 2017), which may partially be due to their varying performance throughout the world (Seufert and Ramankutty 2017). Therefore, their potential benefits mentioned above have not been experienced to the same extent in different parts of the world: high-income countries in temperate regions that produce sufficient food to feed their populations have the most productive organic farming systems and receive the most ecosystem services (Seufert and Ramankutty 2017). Similarly, most research on organic food and farming systems takes place in temperate regions, where the challenges are often less severe than in tropical, sub-tropical, arid and semi-arid regions (Niggli et al. 2016).

Investment in research on organic food and farming systems and other sustainable technologies has increased in recent years but is still marginal compared to research expenditures on agrochemicals, genetic engineering, animal confinement systems and other technologies that are incompatible with organic principles and standards (FAO 2011). Most of the research expenditures have been directed at temperate- and Mediterranean-zone agricultures in Europe and North America, while relatively little capacity exists for research on organic food and farming systems in tropical- and sub-tropical systems, particularly in lowincome countries of Africa, Asia and Latin America (Niggli et al. 2016; Seufert et al. 2012). Institutional research capacity can be measured by several parameters: human resources and support staff trained to conduct research; land, laboratory space and other facilities dedicated to research; publications and other information dissemination for technology transfer; and direct research expenditures (Barbercheck et al. 2012; Lockeretz and Anderson 1993; National Research Council 1989; Ruttan 1980; Ruttan and Hayami 1973). While none of these metrics completely reflect institutional capacity, research expenditures can be compared across farming systems, favouring high-income countries with high-cost structures (Pardey et al. 2013). However, before assessing the current capacity for organic farming research, it is important to consider the context in which organic farming has evolved in different parts of the world. 


\section{History and current state of organic food and farming systems research}

Research on organic food and farming systems originated with on-farm trials in European in the 1920s and 1930s, with little research published in peer-reviewed journals prior to the 1980s (Niggli et al. 2016; Peters 1979). The first scientific conference proceedings were published in 1977 as an output of the first IFOAM Scientific World Conference in Switzerland (Besson and Vogtmann 1978). Several private research institutions emerged in the 1970s and 1980s, including the Research Institute of Organic Agriculture (FiBL) in Switzerland in 1973 and the Elm Farm Research Centre in the UK in 1980. In 1992, the European Union (EU) enacted a regulation (EEC 1991) that defined organic farming, and authorized support payments for conversion and maintenance are granted under the EU's Common Agricultural Policy (EEC 2011). Since 2004, two EU action plans (EEC 2004, 2014) have supported organic farming with promotion campaigns, standards development and research funding. Similar developments have taken place in European countries that are not part of the EU such as Switzerland, where organic farming is both legally protected and financially supported (OECD 2015). A good example of a common characteristic among different European countries (EU and non-EU) to fine-tune social, ecological and technological innovations is the European Partnership on agricultural productivity and sustainability (European Commission 2012).

In the USA, the Rodale Institute was founded in 1947, but prior to 1980 , most of their research results were published in-house (Minnich and Hunt 1979; Rodale 1961; Rodale 1978). In 1980, the US Department of Agriculture published its first report on organic farming that was largely favourable and called for policies to encourage the adoption of organic farming, including research on organic food and farming systems (Youngberg 1980). However, the report was disregarded by the incoming Reagan administration (Youngberg and DeMuth 2013). While the USA had publicly funded "low-input" and "sustainable" agriculture programs going back to the 1980s, the first US program specifically dedicated to organic farming research was authorized in the 2002 Farm Bill as the Organic Research and Extension Initiative (OREI) [US Public Law 107-171 2002]. Between 2002 and 2014, the UDSA funded 189 projects on organic food and farming systems, mostly at public agricultural research institutions (Schonbeck et al. 2016).

Although Australia has the largest area under organic production of any nation, relatively little research on organic food and farming systems is conducted there (Wynen and Mitchell 2013). New Zealand has no programs dedicated to organic food and farming systems research. As a result, most research was of short-term nature and has been done ad hoc (Niggli et al. 2016).

Research capacity for organic food and farming systems lags behind in Africa and most of Asia and Latin America. Africa, which faces the greatest challenges in organic farming, also has the least research capacity (Niggli et al. 2016). Despite the lack of research conducted on organic farming systems in Africa, research conducted on agroforestry (Mbow et al. 2014), agroecology (Nyantakyi-Frimpong et al. 2016), improved pastoral and integrated farming systems, Low External Input Sustainable Agriculture (LEISA), permaculture and sustainable intensification (van der Laan et al. 2017) may be relevant to the development of organic farming systems adapted to African conditions. Parts of Asia, specifically Japan, South Korea, Saudi Arabia and Iran, all have relatively well-funded research programs on organic food and farming systems (Niggli et al. 2016). China and India, however, have invested very little relative to the number of organic farms in those countries (Niggli et al. 2016). In Latin America and the Caribbean, the three countries Argentina, Mexico and Brazil account for most of the research on organic food and farming systems, which are largely targeted at export crops (Niggli et al. 2016), even though research on agroecology is also gaining momentum, particularly in Brazil (Agenda Gotsch 2017). In other countries (e.g. Colombia, Costa Rica, Nicaragua and Peru), more research is conducted on agroecology in subsistence crops, but the expenditures are relatively small compared to the export-oriented sector.

One way to compare support for research on organic food and farming systems is to look at direct expenditures on respective research programs. TIPI estimated the annual amount of money that was directly spent on organic food and farming systems research on the various continents (Niggli et al. 2016). Table 1 contains regional estimates of annual expenditures on organic food and farming systems research by continent (Niggli et al. 2016), as well as area under organic production and organic retail sales. The research spending estimations were based on national and transnational 
Table 1 Worldwide key indicators for organic food and farming systems research

\begin{tabular}{lcclc}
\hline Continent & $\begin{array}{l}\text { Estimated } \\
\text { research } \\
\text { expenditures } \\
\text { (million US\$) }\end{array}$ & $\begin{array}{l}\text { Organic } \\
\text { farmland } \\
\text { (million } \\
\text { hectares) }\end{array}$ & $\begin{array}{l}\text { Research } \\
\text { expenditures } \\
\text { per hectare } \\
\text { (US\$) }\end{array}$ & $\begin{array}{l}\text { Retail } \\
\text { sales } \\
\text { (billion }\end{array}$ \\
US\$)
\end{tabular}

Sources: (Niggli et al. 2016; Willer and Lernoud 2016).

review and strategy papers, on the analyses of different national funding schemes' continuous open calls (e.g. Switzerland, Germany, Canada, the USA, Denmark, Sweden, Austria, Australia, Norway, the UK, South Korea, Brazil, Saudi Arabia — only to mention a few) on the analyses of the capacities of state personnel involved in organic agriculture both for research and for teaching and on the results of peer review reports on agricultural research. Many of the documents were not published as they were internal reports. An example of an attempt to estimate the magnitude of organic research spending for some funding schemes and for some selected countries is given in European Commission (2012). Tittonell (2014) came independently from Niggli et al. (2016) to similar magnitudes.

In proportion to area under production, North America and Europe show the highest, and Oceania shows the lowest research expenditures per hectare (Table 1). This reflects the better funding situation in North America and Europe (Niggli et al. 2016). Higher research expenditures for organic food and farming systems in Europe are the result from rapidly growing markets and a positive perception of organic by consumers and citizens (Niggli et al. 2016). The European Commission and many national governments have policies to support organic farming as a means of developing innovative markets while promoting sustainability (Niggli et al. 2016).

For the whole world, an estimated US\$290 million was spent on organic food and farming systems research, which amounts to US\$5.70 per hectare of organic farmland (Table 1). By comparison, the estimate for global public and private expenditures on all agricultural research and development for 2011, the most recent year for which estimates are available, is a total of US $\$ 69.3$ billion (Pardey et al. 2016), making the estimated investment in organic farming research less than $0.5 \%$ of the total investment in all agricultural research and development. Globally, there are approximately 5 billion ha of agricultural land (FAO 2013), and thus, research expenditures per hectare are approximately $\$ 14$ per ha or almost three times as much as for organic. There has been an overall trend of a decline in public sector funding of agricultural research and more corporate investment on proprietary technologies (Fuglie and Toole 2014; Pardey et al. 2013). There is also a widening gap in the relative amounts of agricultural research funds being invested in rich and poor countries (Beintema et al. 2012; Pardey et al. 2016). Private sector investment has focused on biotechnology and innovations that can be protected by patents or other intellectual property rights. Agroecological research seen as compatible with organic farming systems does not provide the same incentives for private sector investment in research and development because their benefits are long-term and are public goods (Vanloqueren and Baret 2009).

\section{The Technology Innovation Platform of IFOAM-Organics International}

TIPI is a one of eight sector platforms of IFOAMOrganics International, which is the umbrella organization of 800 organic organizations and businesses in 100 countries of the world. It was launched in February 2013, at the first Science Day of Biofach - the world's largest organic trade fair, in Nuremberg, Germany - as an established organization with membership and statutes (Niggli et al. 2017) according to the rules of IFOAM - Organics International for sector platforms. TIPI's mission is to serve as a global platform for organic food and farming systems research, innovation and technology transfer. The membership includes organic farmer associations, networks that support organic agriculture, trade associations, government ministries, private companies, consultants, research institutes and university departments that are conducting research on organic food and farming systems. At the second 
Science Day in 2014, participants from all parts of the world reported on the state of organic food and farming systems research in their regions during a set of workshops and focus groups. Those results were presented at a workshop prior to the 18th Organic World Congress in Istanbul, Turkey, in October 2014. Afterwards, the draft agenda, vision and strategy were circulated among stakeholders identified by IFOAM-Organics International from June 2012 to October 2014. Comments were used together with further comments provided at the third Science Day in 2015 to compile the final document that was presented at the fourth Science Day in 2016 (Niggli et al. 2016). At the fifth Science Day in 2017, a condensed version of the extensive document published in 2016 was presented (Niggli et al. 2017). As a concise position paper, this most recent document serves as a basis to develop further policy briefs.

\section{Future development of organic farming}

As organic farming continues to grow, it also evolves and transforms. The evolution of organic farming can be divided into three stages: (1) the pioneer stage (19251980), where organic farming began as a response to the environmental, economic and social problems caused by industrialization and the adoption of agrochemicals; (2) the legitimation stage (1980-2015), where the principles were codified into standards and legally mandated regulatory systems; and (3) the mainstreaming stage (2015-present), where organic farming systems are moving from being a niche to an accepted solution to the challenge of sustainable food production (Niggli et al. 2016). The latter is referred to as "Organic 3.0" and aims at promoting organic food and farming systems as a modern and innovative approach to farming based on organic principles. As opposed to the current approach of certified organic agriculture, Organic 3.0 does not enforce a set of minimum rules to achieve a final static result but is outcome-based and continuously adaptive to the local context. As a culture of continuous improvement through stakeholder-driven initiatives for the transformation of food and farming systems towards higher levels of resilience, sustainability and systemic health, Organic 3.0 is motivated by innovation, transparency and inclusion, while remaining based on local priorities. Methodologically, Organic 3.0 applies a holistic systems approach and also accounts for external costs of agriculture. As such, research in Organic 3.0 will require methodological innovations in evaluating ecosystem and economic performance (Arbenz 2014).

\section{Pathways of future research}

Most of the current research on organic food and farming systems addresses the needs of the Organic 3.0 or mainstreaming stage. Therefore, TIPI advocates for three main pathways for future research on organic food and farming systems follow (Table 2). Pathway $1 \mathrm{im}-$ proves and enables organic farming systems to become a widely preferred land use system in rural areas worldwide. Pathway 2 improves and enables organic food and farming systems to feed the world and conserve the planet's natural resources. Pathway 3 enables organic food and farming systems to produce healthy food in a fair way for the well-being of all. These three pathways are proposed as a way to have secure food and protected ecosystems in the future (Niggli et al. 2016).

From these visions, we derived the following strategy for global organic food and farming research and innovation, which may be implemented by following the three pathways and associated research implications mentioned above.

\section{Strategies of organic food and farming systems research}

Through a lengthy strategic planning process that included researchers and the beneficiaries of organic farming research, TIPI identified three strategic research approaches, which will help advancing global organic food and farming systems research and innovation in the context of the three pathways described above ("rural empowerment", "eco-functional intensification" and "healthy and fair food"; Niggli et al. 2016):

1. Develop research methods appropriate for organic food and farming systems.

2. Renew partnerships between farmers, farm advisors, scientists and consumers.

3. Integrate technological, social and ecological dimensions of innovation.

Following these three strategic approaches is likely to lead to a transformation of food and farming systems towards higher levels of resilience, sustainability and 
Table 2 Pathways for future development of organic food and farming systems with corresponding visions and research implications (source: Niggli et al. 2016)

\begin{tabular}{ll}
\hline Pathway & Vision \\
\hline $\begin{array}{l}\text { Pathway 1: Organic agriculture } \\
\text { will become the preferred }\end{array}$ & $\begin{array}{c}\text { Organic agriculture will be the preferred land } \\
\text { use model and thus empower rural }\end{array}$ \\
land use system in rural & economies. Viable local economies will \\
areas worldwide. & attract people, improve livelihoods and halt \\
& migration to cities. Organic farming will \\
& intensify partnerships between consumers \\
& and producers by fostering dialogues \\
& between them. Through best use of natural \\
& and social resources, organic agriculture \\
& will be a powerful intensification strategy \\
in rural areas and for subsistence farming.
\end{tabular}

Pathway 2: Secure food and ecosystems through ecofunctional intensification
Pathway 3: Organic agriculture will produce healthy food in a fair way for the well-being of all.
Eco-functional intensification will increase the availability of food and stabilize food supplies. Use of non-renewable resources and off-farm inputs will become obsolete. High standards in animal welfare will be maintained and sustainable ecosystem management will be state of the art. Organic farming will minimize negative trade-offs between productivity and sustainability, making it the benchmark for the responsible and precautionary use of science in food and farming systems. Organic farmers will be the best agricultural ecosystem managers, coresearchers and resource optimizers.

Healthy diets, consisting of fresh and whole foods with intrinsic qualities, will be a standard and are only minimally altered by processing. In terms of taste, regional variation will be preferred over artificial design. Organic farmers, food processors and distributors will jointly spearhead the
Implications for future research

Develop value added food chains in rural economies; sourcing regional, high-quality foods from organic farms and using local processing, packaging and labelling units to create new products by traditional food techniques and innovative technologies

Include all stakeholders in setting research priorities; farmers, traders, processors, researchers, retailers, consumers and future generations should all be involved in improving the quality of rural life and sharing the benefits of organic farming

Establish farmer-researcher innovation groups to boost co-innovation in rural areas

Improve the economic viability of short food chains through information and communication technologies, as well as social media

Specify models, metrics and key indicators and use them to collect and analyse data about the comparative environmental and social costs of organic and conventional agriculture

Adopt a perspective that soil, plant and animal health is the norm to investigate, understand and develop preventive measures (cultural, physical and biological), aiming at replacing the routine use of pesticides and animal medicine

Breed crops and livestock that are better adapted to local conditions as well as low external input systems and have sustainable yields and greater nutritional quality

Employ modern scientific methods to test, validate and, where appropriate, adjust traditional knowledge and locally adapted systems to improve the resilience of farming systems

Design farming system and natural habitats that enhance functional biodiversity, increase abundance of pollinators, biological control agents and other beneficial organisms, efficiently cycle nutrients, and create buffer zones to protect critical ecological areas

Increase sustainable yields through improved crop rotations, polycultures, nutrient recycling and variety selection

Enhance soil building to increase organic matter, sequester carbon, maintain and improve soil fertility and improve systems' resilience, particularly in tropical and arid zones

Investigate the interactions between (organic) food quality and human health, looking at the effects of nutrient density, secondary plant nutrients, and reduced contamination with pesticides and other chemicals 
Table 2 (continued)

\begin{tabular}{|c|c|c|}
\hline Pathway & Vision & Implications for future research \\
\hline & \multirow{5}{*}{$\begin{array}{l}\text { transition to more conscious consumption } \\
\text { patterns and the renaissance of authentic } \\
\text { traditional foods. Members of the organic } \\
\text { movement will be innovative in the design } \\
\text { of cooperative and participative models of } \\
\text { transport and safe and traceable food } \\
\text { systems. }\end{array}$} & $\begin{array}{l}\text { Develop and improve technologies to recover } \\
\text { organic wastes, so that they can be safely and } \\
\text { efficiently returned to the soil ("cradle-to-cradle") }\end{array}$ \\
\hline & & $\begin{array}{l}\text { Evaluate biodiversity between (inter-specific) and } \\
\text { within (intra-specific) species of plants and } \\
\text { animals for their ecological resilience and the } \\
\text { health well-being of animals and humans }\end{array}$ \\
\hline & & $\begin{array}{l}\text { Examine and adapt traditional food processing using } \\
\text { modern techniques to improve the quality and } \\
\text { performance of natural, authentic and heritage } \\
\text { foods without losing their essential characteristics }\end{array}$ \\
\hline & & $\begin{array}{l}\text { Investigate the causes of and ways to prevent } \\
\text { contamination with pesticides, genetically } \\
\text { modified organisms and other contaminants } \\
\text { prohibited in organic production and handling } \\
\text { from entering organic food chains }\end{array}$ \\
\hline & & $\begin{array}{l}\text { Invent and develop more ecologically friendly } \\
\text { packaging that is made from renewable resources, } \\
\text { can be reused and is recyclable }\end{array}$ \\
\hline
\end{tabular}

systemic health, the achievement of which will require a restructuring of how research is conducted. Disciplines will be required to interact in a way they have not done previously. Metrics for performance should be developed to look at more than short-term productivity and profitability, without neglecting the need for sufficient production or to make profits. To conduct valid, evidence-based research on organic food and farming systems, research needs to continue to rely on welldesigned, maintained and controlled experiments that meet the standards of scientific peer review. However, unlike most experimental research carried out in the past, novel research will require multidisciplinary teams who integrate components research into holistic farming system approaches.

Develop research methods appropriate for organic food and farming systems

In low-input countries, participatory research on agroecology and farming systems has become a viable alternative. So, too, agricultural research in richer countries increasingly emphasizes the societal context and respects the limitations pre-set by landscapes, abiotic and biotic site conditions. Hence, sustainable, ecological or eco-functional intensification has become the predominant goals of agricultural research (Tittonell
2014). System-related researches such as soil fertility management trials need to look at long-term and synergistic effects of crop rotations and the storage of nutrients slowly released by biological processes. With respect to pest and disease management, new tools to measure the efficacy of biological control options need to be developed. Organic livestock systems research need to focus on preventive measures that maintain health, rather than on developing new cures for diseases.

Farming systems research requires more coordination and thus monetary overhead than component research and takes longer to produce tangible results. Because of its complexity, farming systems research has historically been more difficult to design and manage than controlled experiments (Collinson 2000). Replication is complicated by the site specificity of results and interactions of individual parts of the system that may turn out to be different if the same research is carried out at another site. Moreover, it is not possible to remove the human element from the system to the same degree as in controlled experiments. Evaluating the sustainability and ecological properties of farming systems often involves complex methodologies that are challenging for farmer collaborators to conduct without proper training (Lightfoot and Barker 1988; Lightfoot and Noble 2001; Pretty 1994). However, instead of removing the human element, farmer behaviour and 
thus management are qualitative factors that should be considered as much a part of the farming system as its biophysical elements. Participatory farming systems research can be adaptive when it is interactive, with a feedback loop that involves the farmer and social scientists (Darnhofer et al. 2010).

Best management practices in organic food and farming systems are based on the dimensions of social, ecological, economic, cultural and accountability (SOAAN 2013). As such, performance needs to be measured by criteria other than mere yield and profitability. The social criteria require that the system be equitable and rights-based. The ecologically relevant metrics are whether a system is stable and resilient, and whether it produces sustainable yields in the long run. Sustainable economic performance can be measured by the long-term effects in returns to the farmer's work and financial equity, rather than short-term profits. Farming systems and the technologies used need to respect cultural norms. Finally, organic operations are required to be held accountable for meeting these criteria. In this respect, the developments of tools that analyse farms, businesses and entire food chains including diets and nutrition patterns across a variety of sustainability themes and numerous case-specific indicator sets (e.g. RISE and SMART; Schader et al. 2014) are steps in the right direction.

Renew partnerships between farmers, farm advisors, scientists and consumers

Research institutions are not going to restructure their programs unless there are incentives to do so, and the restructuring needs to be understood, accepted and broadly supported by the researchers in those institutions. Given the limited capacity for organic food and farming systems research, the regulatory constraints on organic farming research, the multiple research objectives for designing experiments for such systems, and the lack of incentives to conduct research and develop technologies that can be used for organic production, post-harvest handling and processing, researchers working on organic food and farming systems have a different relationship to farmers than researchers working on conventional food and farming systems (Auburn and Baker 1992; Barbercheck et al. 2012; Harp and Sachs 1992; Koenig and Baker 2002; Vanloqueren and Baret 2009). In organic food and farming systems, farmers, farm advisors and scientists collaborate as co- innovators, sharing knowledge of current best management practices (Nicolay and Fliessbach 2012), and farmers share information among themselves using the "farmer-to-farmer methodology", which was developed and successfully implemented for the first time in Cuba during the mid-1990s (Rosset et al. 2011). Such a relationship contrasts with viewing farmers as clients with limited access to knowledge. Given the limited amount of certified organic land in most public and private research institutions that are not working specifically on organic, on-farm research with active participation of farmers is a necessity. Models for successful farmerresearcher partnerships include participatory plant breeding and farmer innovation networks.

Participatory plant breeding (PPB) was pioneered in developing regions to help smallholders in unfavourable environments (Ceccarelli and Grando 2007). It was a response to breeding programs that did not address genetic-by-environment-by-management $(\mathrm{G} \times \mathrm{E} \times \mathrm{M})$ interactions. PPB gains access to disease resistant varieties (Robinson 1996) and is locally adapted to resource-limited conditions, particularly drought-prone areas (Ceccarelli et al. 2010), marginal soils (Weltzien et al. 2003) and other stress conditions. Selecting suitable varieties for organic farming conditions through PPB has been an on-going collaborative effort between farmers and plant breeders in Europe and North America and has led to several trans-Atlantic success stories (Desclaux et al. 2012; van Bueren et al. 2011).

Farmers are often innovators and pioneers, and peerto-peer technology transfer can by-pass institutional and corporate structures, giving farmers direct access to technology. Farmer innovation networks can also collaborate with institutions to demonstrate and apply the results of research. Farmer innovation networks may be local, regional or global in their scope. One model, which started in the 1980s in response to the US farm crisis, is the Practical Farmers of Iowa (PFI) (Practical Farmers of Iowa 2017). PFI is a farmer-led, memberdriven non-profit organization with a mission to advance profitable, ecologically sound and communityenhancing approaches to agriculture through farmerled investigation and information sharing. Another model is Farm Hack, a worldwide community of farmers that shares open-source technical solutions both online and at local events (Farm Hack 2017). Syprobio, another farmer innovation network, was a EuropeAidfunded project that worked with farmers in Benin, Burkina Faso and Mali to identify production challenges 
and solutions for cotton growers. Based on their own ideas and experiences, farmer groups cooperatively identified challenges and developed research-based innovations in the areas of soil fertility, plant health, seeds, crops management, and socio-economics (Nicolay and Fliessbach 2012).

Farmer networks conducting on-farm research are currently common in Europe. Examples are the Farmers' Organic Research Clubs in the UK, which are coordinated by The Organic Research Centre in Newbury, UK, and cover topics such as participatory breeding, animal health or arable cropping systems (The Organic Research Centre 2017). Other examples include the FiBL Austria-coordinated "Bionet" in Austria (Bionet 2017) researching arable and vegetable cropping systems, as well as several farmer innovation groups of FiBL Switzerland (Walkenhorst et al. 2006; Klocke et al. 2010) working on dairy health prevention, reduced-till arable cropping systems, functional biodiversity in vegetable systems and mix-cropping of legumes and cereals. The Organic Knowledge Network Arable is an all-European network of farmer-scientist cooperation coordinated by the IFOAM-EU Group and funded by the European Union (OK-Net Arable 2017).

Another prospective strategic partnership would be with those researchers who are working on LEISA, integrated pest management, agroecology, agroforestry, sustainable intensification and other alternatives to the conventional paradigm, particularly in regions that have limited research capacity overall such as Africa. Partnering with and building on these alternatives to conventional production may be a more viable strategy for long-run progress for African organic food and farming systems than developing a parallel research structure dedicated solely to organic farming research.

Integrate technological, social and ecological dimensions of innovation

Innovation happens in three dimensions: social, ecological and technical (Niggli et al. 2016). While most of the literature on innovation focuses on the third dimension, the other two are no less important in organic food and farming systems. Organic farmers have mixed opinions about new technologies. On one hand, they are generally sceptical of technical innovations and have rejected many new technologies because of the risks they pose to ecological, social and economic systems, as well as potentially irreversible adverse consequences that might come along with adoption. Most prominent of these in recent years is the rejection of genetic engineering by organic farmers (Vanloqueren and Baret 2009; Verhoog 2007). At the same time, organic farmers are more likely to be leading social and ecological innovators compared to conventional farmers. Examples include the adoption of community supported agriculture (CSA) (Henderson and Van En 2007), habitat management to increase populations of beneficial organisms (Bengtsson et al. 2005; Garfinkel and Johnson 2015; Hardman et al. 2016; Hole et al. 2005) and the adoption of biological insect control (Goldberger and Lehrer 2016).

Long-term agricultural productivity is expected to depend on viable functioning of natural systems that reduce trade-offs between production and ecosystems services, which include food, feed, fuel and fibre production as well as clean air and water, biologically active soils and wildlife (MEA 2005; TEEB 2010). Valuing the benefits of organic food and farming systems and internalizing the external costs of agriculture would create incentives for the adoption of more sustainable practices (Pretty et al. 2001). However, to do so would require sound methodologies to measure external costs caused by the use of farm chemicals and the value of ecosystem services (Andres and Bhullar 2016). While there are efforts underway to quantify these external costs and benefits, the models are subject to debate and the data can often be difficult to collect and quantify, but they can be assessed qualitatively (Kremen and Miles 2012). Unlike market goods and services, ecosystem services are not traded for money. Ecosystem services was created as a metaphorical concept, but they cannot be valued because they are not purchased in the marketplace and involve complex ecological and economic interaction that are abstract and intergenerational (Norgaard 2009). Proxy values need to be estimated based on imperfect information. Political contexts lead to those values being subjective based on stakeholder perspective (Hauck et al. 2013). Because many ecosystem services create costs and benefits over the long run that are difficult to predict, their value to future generations is likely to be discounted and not fairly evaluated (Goulder and Kennedy 1997). Hence, new methodologies need to be developed to integrate the dimension of natural and social sciences, which may even require a restructuring of academic disciplines. 


\section{Conclusions and outlook}

Globally, public and private research spending on the specific challenges and problems of organic food and farming systems is scarce and does probably not exceed $1 \%$ of all research spending for food and farming. Capacity is especially needed in Africa, Asia and Latin America. Evidence-based scientific findings and successful case studies foster the credibility of organic farming and help to discover research needs worthy of scientific inquiry. TIPI has taken the first steps towards serving these purposes by conducting a survey of specific research needs both globally and in the different specific regions and prioritizing the most pressing questions. New research methods appropriate for organic food and farming systems will need to be developed to address problems that have not been solved by existing research programs. Building and strengthening farmerresearcher networks will be key to the success of implementing these new methods, particularly in resource constrained regions that lack research capacity. Non-governmental organizations and social scientists are expected to play a vital role in building such networks. The social and ecological dimensions of innovation will need to be integrated with the technological applications that are developed and transferred if organic farmers are expected to adopt new practices. Models for technology diffusion may also need to be refined and revised to go beyond an input substitution model, changing the roles of extension and the private farm services sector.

TIPI has a role of gathering evidence-based, quantitative and comprehensive information about organic food and farming systems research worldwide through databases and websites (Organic Research 2017). Above all, TIPI was established to facilitate interactions between researchers and beneficiaries of research to make the global research agenda visible and create policies that promote organic agricultural research. Both an actor-driven information exchange and an improved visibility of organic research to address the Sustainable Development Goals (UN 2017) represent only the first steps of TIPI towards a future global action plan for investments in organic food and farming systems research. This has the goal to both meet the growing demand for organic food and fibre and to tap the potential of organic food and farming systems to be a leading model for the resolution of the sustainability problems the world faces. Ultimately, it will be the farmers who will make the decisions needed to innovate and implement the innovations needed to advance organic farming's state of the art. Farmer-led innovation and farmerto-farmer technology transfers are expected to be the main way that dissemination of innovations takes place in organic food and farming systems. Therefore, in a next step, TIPI will strengthen an active participation of as many IFOAM - Organic International member organizations as possible. Finally, as research in organic food and farming systems is expected to generate innovations with applications beyond the organic sector, benefitting future generations, TIPI's third step will be to actively involve and represent a growing number of organic farmers, farm advisors and scientist in the pursue and actor-driven implementation of the Sustainable Development Goals.

Acknowledgments We wish to express our gratitude to the following people for their contributions to the content of this manuscript: Reza Ardakani, Vugar Babayev, Mahesh Chander, Jennifer Chang, Kim Seok Chul, Eduardo Cuoco, Malgorzata Conder, David Gould, Andrew Hammermeister, Marco Hartmann, Brendan Hoare, Shaikh Tanveer Hossain, Irene Kadzere, Nic Lampkin, Karen Mapusua, Charles Merfield, Carolin Möller, Gian Nicolay, Toshio Oyama, Vitoon Panyakul, Gerold Rahmann, Mohammedreza Rezapanah, Felix Ruhland, Otto Schmid, Arun K. Sharma, Sang Mok Sohn, Brian Ssebunya, Gabriela Soto, Nazim Uddin, Maria Wivstad, Els Wynen and Qiao Yuhui. Thanks to Kurt Riedi for the figure layouts.

\section{References}

Agenda Gotsch (2017) Syntropic agriculture. http://agendagotsch. com/. Accessed 20 Jul 2017

Altieri MA, Ponti L, Nicholls CI (2005) Enhanced pest management through soil health: toward a belowground habitat management strategy. Biodyn (Summer):33-40

Andersson GK, Rundlöf M, Smith HG (2012) Organic farming improves pollination success in strawberries. PLoS One 7: e31599. doi:10.1371/journal.pone.0031599

Andres C, Bhullar GS (2016) Sustainable intensification of tropical agro-ecosystems: need and potentials. Front Environ Sci 4:5. doi:10.3389/fenvs.2016.00005

Arbenz M (2014) It is time for organic 3.0. Outlook. In: Willer H, Lernoud J (eds) The world of organic agriculture. Statistics and emerging trends 2014, revised version of February 24, 2014. Research Institute of Organic Agriculture (FiBL), International Federation of Organic Agriculture Movements (IFOAM) - Organics International, Frick, Bonn, pp 275

Armengot L, Barbieri P, Andres C, Milz J, Schneider M (2016) Cacao agroforestry systems have higher return on labor compared to full-sun monocultures. Agron Sustain Dev 36:70. doi:10.1007/s13593-016-0406-6 
Auburn JS, Baker BP (1992) Re-integrating agricultural research. Am J Altern Agric 7:105-110. doi:10.1017/S0889189300004604

Baker BP, Benbrook CM, Groth E III, Benbrook KL (2002) Pesticide residues in conventional, integrated pest management (IPM)-grown and organic foods: insights from three US data sets. Food Addit Contam 19:427-446. doi:10.1080 /02652030110113799

Barański M, Srednicka-Tober D, Volakakis N, Seal C, Sanderson R, Stewart GB, Benbrook C, Biavati B, Markellou E, Giotis C, Gromadzka-Ostrowska J, Rembiałkowska E, SkwarłoSońta K, Tahvonen R, Janovská D, Niggli U, Nicot P, Leifert C (2014) Higher antioxidant and lower cadmium concentrations and lower incidence of pesticide residues in organically grown crops: a systematic literature review and meta-analyses. Br J Nutr 112:794-811. doi:10.1017 /S0007114514001366

Barbercheck M, Kiernan NE, Hulting AG, Duiker S, Hyde J, Karsten H, Sanchez E (2012) Meeting the 'multi-'requirements in organic agriculture research: successes, challenges and recommendations for multifunctional, multidisciplinary, participatory projects. Renew Agric Food Syst 27:93-106. doi:10.1017/S1742170511000214

Beintema N, Stads GJ, Fuglie K, Heisey P (2012) ASTI Global Assessment of Agricultural R\&D Spending | International Food Policy Research Institute, Washington, D.C. Agricultural Science and Technology Indicators, Rome | Global Forum on Agricultural Research, Rome

Benbrook CM, Baker BP (2014) Perspective on dietary risk assessment of pesticide residues in organic food. Sustainability 6:3552-3570. doi:10.3390/su6063552

Benbrook CM, Butler G, Latif MA, Leifert C, Davis DR (2013) Organic production enhances milk nutritional quality by shifting fatty acid composition: a United States-wide, 18month study. PLoS One 8:e82429. doi:10.1371/journal. pone. 0082429

Bengtsson J, Ahnström J, Weibull A-C (2005) The effects of organic agriculture on biodiversity and abundance: a metaanalysis. J Appl Ecol 42:261-269. doi:10.1111/j.13652664.2005.01005.x

Besson JM, Vogtmann H (1978) Towards a sustainable agriculture. Conference proceedings of the first IFOAM conference, held in Sissach 1977 | Verlag Wirz AG, Aarau, Switzerland

Bionet (2017) Netzwerk von Transferbetrieben für den biologischen Ackerbau. http://www.bio-net.at/startseite. html. Accessed 20 Jul 2017

Brandt K, Leifert C, Sanderson R, Seal CJ (2011) Agroecosystem management and nutritional quality of plant foods: the case of organic fruits and vegetables. Crit Rev Plant Sci 30:177197. doi:10.1080/07352689.2011.554417

Ceccarelli S, Grando S (2007) Decentralized-participatory plant breeding: an example of demand driven research. Euphytica 155:349-360. doi:10.1007/s10681-006-9336-8

Ceccarelli S, Grando S, Maatougui M, Michael M, Slash M, Haghparast R, Rahmanian M, Taheri A, Al-Yassin A, Benbelkacem A, Labdi M, Mimoun H, Nachit M (2010) Plant breeding and climate changes. J Agric Sci 148:627637. doi:10.1017/S0021859610000651

Collinson M (2000) A history of farming systems research. CABI and Food and Agriculture Organization of the United Nations, Rome
Crowder DW, Reganold JP (2015) Financial competitiveness of organic agriculture on a global scale. Proc Natl Acad Sci 112: 7611-7616. doi:10.1073/pnas.1423674112

Dangour AD, Lock K, Hayter A, Aikenhead A, Allen E, Uauy R (2010) Nutrition-related health effects of organic foods: a systematic review. Am J Clin Nutr 92:203-210. doi:10.3945/ajcn.2010.29269

Darnhofer I, Bellon S, Dedieu B, Milestad R (2010) Adaptiveness to enhance the sustainability of farming systems. A review. Agron Sustain Dev 30:545-555. doi:10.1051/agro/2009053

de Ponti T, Rijk B, van Ittersum MK (2012) The crop yield gap between organic and conventional agriculture. Agric Syst 108:1-9. doi:10.1016/j.agsy.2011.12.004

Desclaux D, Ceccarelli S, Navazio J, Coley M, Trouche G, Aguirre S, Weltzien E, Lançon J (2012) Centralized or decentralized breeding: the potentials of participatory approaches for low-input and organic agriculture. In: Lammerts van Bueren ET, Myers JR (eds) Organic crop breeding. Wiley-Blackwell, Oxford, pp 99-123. doi:10.1002/9781119945932.ch6

Drinkwater LE, Wagoner P, Sarrantonio M (1998) Legume-based cropping systems have reduced carbon and nitrogen losses. Nature 396:262-264. doi:10.1038/24376

EEC (1991) Council regulation (EEC) No. 2092/91 of 24 June 1991 on organic production of agricultural products and indications referring thereto on agricultural products and foodstuffs. http://eur-lex.europa.eu/legalcontent/EN/TXT/?uri=URISERV\%3A121118. Accessed 20 Jul 2017

EEC (2004) European Action Plan for Organic Food and Farming. http://eur-lex.europa.eu/LexUriServ/LexUriServ.do?uri= COM:2004:0415:FIN:EN:PDF. Accessed 20 Jul 2017

EEC (2011) Proposal for a Regulation of the European Parliament and of the Council establishing rules for direct payments to farmers under support schemes within the framework of the common agricultural policy. European Commission 19 October 2011. Accessed 20 Jul 2017

EEC (2014) Action Plan for the future of Organic Production in the European Union. https://ec.europa. eu/agriculture/organic/sites/orgfarming/files/docs/body/act en.pdf. Accessed 20 Jul 2017

El-Hage Scialabba N, Hattam C (eds) (2002) Organic agriculture, environment and food security, Environment and Natural Resources Series, Vol 4. Food and Agriculture Organization of the United Nations, Rome

European Commission (2012) A decade of EU-funded, low-input and organic agriculture research (2000-2012). Publications Office of the European Union, Luxembourg. doi:10.2777 /19796

Eyhorn F, Ramakrishnan M, Mäder P (2007) The viability of cotton-based organic farming systems in India. Int J Agric Sustain 5:25-38. doi:10.1080/14735903.2007.9684811

FAO (2011) Payments for ecosystem services and food security. Food and Agriculture Organization of the United Nations, Rome

FAO (2013) FAO statistical yearbook. Food and Agriculture Organization of the United Nations, Rome

Farm Hack (2017) Farm hack. http://farmhack.org. Accessed 20 Jul 2017

Fischer J, Brosi B, Daily GC, Ehrlich PR, Goldman R, Goldstein J, Lindenmayer DB, Manning AD, Mooney HA, Pejchar L, 
Ranganathan J, Tallis H (2008) Should agricultural policies encourage land sparing or wildlife-friendly farming? Front Ecol Environ 6:380-385. doi:10.1890/070019

Fließbach A, Oberholzer HR, Gunst L, Mäder P (2007) Soil organic matter and biological soil quality indicators after 21 years of organic and conventional farming. Agric Ecosyst Environ 118:273-284. doi:10.1016/j.agee.2006.05.022

Forster D, Andres C, Verma R, Zundel C, Messmer MM, Mäder P (2013) Yield and economic performance of organic and conventional cotton-based farming systems - results from a field trial in India. PLoS One 8:e81039. doi:10.1371/journal. pone.0081039

Frieben B, Köpke U (1995) Effects of farming systems on biodiversity. In: Isart J, Llerena JJ (eds) Proceedings of 1st ENOF Workshop-Biodiversity and land use: the role of organic farming. Multitext, Barcelona, pp 11-21

Fuglie KO, Toole AA (2014) The evolving institutional structure of public and private agricultural research. Am J Agric Econ 96:862-883. doi:10.1093/ajae/aat107

Fuller RJ, Norton LR, Feber RE, Johnson PJ, Chamberlain DE, Joys AC, Mathews F, Stuart RC, Townsend MC, Manley WJ, Wolfe MS, Macdonald DW, Firbank LG (2005) Benefits of organic farming to biodiversity vary among taxa. Biol Lett 1: 431-434. doi:10.1098/rsbl.2005.0357

Gabriel D, Roschewitz I, Tscharntke T, Thies C (2006) Beta diversity at different spatial scales: plant communities in organic and conventional agriculture. Ecol Appl 16:20112021. doi:10.1890/1051-0761(2006)016[2011 :BDADSS]2.0.CO;2

Gadermaier F, Berner A, Fließbach A, Friedel JK, Mäder P (2011) Impact of reduced tillage on soil organic carbon and nutrient budgets under organic farming. Renew Agric Food Syst 27: 68-80. doi:10.1017/S1742170510000554

Garfinkel M, Johnson M (2015) Pest-removal services provided by birds on small organic farms in northern California. Agric Ecosyst Environ 211:24-31. doi:10.1016/j.agee.2015.04.023

Gattinger A, Muller A, Haeni M, Skinner C, Fliessbach A, Buchmann N, Mäder P, Stolze M, Smith P, El-Hage Scialabba N, Niggli U (2012) Enhanced top soil carbon stocks under organic farming. Proc Natl Acad Sci 109: 18226-18231. doi:10.1073/pnas.1209429109

Goldberger JR, Lehrer N (2016) Biological control adoption in western US orchard systems: results from grower surveys. Biol Control 102:101-111. doi:10.1016/j. biocontrol.2015.09.004

Gomiero T, Pimentel D, Paoletti MG (2011) Environmental impact of different agricultural management practices: conventional vs. organic agriculture. Crit Rev Plant Sci 30:95-124. doi:10.1080/07352689.2011.554355

Goulder LH, Kennedy D (1997) Valuing ecosystem services: philosophical bases and empirical methods. In: Daly G (ed) Nature's services: societal dependence on natural ecosystems. Island Press, Washington, D.C., pp 23-47

Hardman CJ, Harrison DP, Shaw PJ, Nevard TD, Hughes B, Potts SG, Norris K (2016) Supporting local diversity of habitats and species on farmland: a comparison of three wildlifefriendly schemes. J Appl Ecol 53:171-180. doi:10.1111 /1365-2664.12557

Harp A, Sachs C (1992) Public agricultural researchers: reactions to organic, low input and sustainable agriculture. Agric Hum Values 9:58-63. doi:10.1007/BF02217965
Hauck J, Görg C, Varjopuro R, Ratamäki O, Jax K (2013) Benefits and limitations of the ecosystem services concept in environmental policy and decision making: some stakeholder perspectives. Environ Sci Pol 25:13-21. doi:10.1016/j. envsci.2012.08.001

Henderson E, Van En R (2007) Sharing the harvest. A citizen's guide to community supported agriculture, 2nd edition | Chelsea Green Publishing, White River Junction, VT

Hole DG, Perkins AJ, Wilson JD, Alexander IH, Grice PV, Evans AD (2005) Does organic farming benefit biodiversity? Biol Conserv 122:113-130. doi:10.1016/j.biocon.2004.07.018

Holzschuh A, Steffan-Dewenter I, Kleijn D, Tscharntke T (2007) Diversity of flower-visiting bees in cereal fields: effects of farming system, landscape composition and regional context. J Appl Ecol 44:41-49. doi:10.1111/j.1365-2664.2006.01259.x

IFOAM (2005) Principles of organic agriculture. IFOAM, Bonn

Jerkins D, Ory J (2016) National Organic Research Agenda. Organic Farming Research Foundation, Santa Cruz

Klocke P, Ivemeyer S, Butler G, Maeschli A, Heil F (2010) A randomized controlled trial to compare the use of homeopathy and internal teat sealers for the prevention of mastitis in organically farmed dairy cows during the dry period and 100 days post-calving. Homeopathy 99:90-98. doi:10.1016/j. homp.2009.12.001

Koenig RL, Baker B (2002) U.S. National Organic Program Standards: implications for researchers. APSnet features. h t t p : / / w w w a p s n e t.

org/publications/apsnetfeatures/Pages/Organics.aspx. Accessed 20 Jul 2017. doi:10.1094/APSnetFeature-20021102

Kragten S, de Snoo GR (2008) Field-breeding birds on organic and conventional arable farms in the Netherlands. Agric Ecosyst Environ 126:270-274. doi:10.1016/j. agee.2008.02.006

Kragten S, Trimbos KB, de Snoo GR (2008) Breeding skylarks (Alauda arvensis) on organic and conventional arable farms in The Netherlands. Agric Ecosyst Environ 126:163-167. doi:10.1016/j.agee.2008.01.021

Kramer SB, Reganold JP, Glover JD, Bohannan BJM, Mooney HA (2006) Reduced nitrate leaching and enhanced denitrifier activity and efficiency in organically fertilized soils. Proc Natl Acad Sci 103:4522-4527. doi:10.1073 /pnas.0600359103

Kremen C, Miles A (2012) Ecosystem services in biologically diversified versus conventional farming systems: benefits, externalities, and trade-offs. Ecol Soc 17:40. doi:10.5751 /ES-05035-170440

Lightfoot C, Barker R (1988) On-farm trials: a survey of methods. Agric Adm Ext 30:15-23. doi:10.1016/0269-7475(88 )90045-1

Lightfoot C, Noble R (2001) Tracking the ecological soundness of farming systems: instruments and indicators. J Sustain Agric 19:9-29. doi:10.1300/J064v19n01_03

Lockeretz W, Anderson MD (1993) Agricultural research alternatives, vol Vol 3. University of Nebraska Press, Lincoln

Lotter DW, Seidel R, Liebhardt W (2003) The performance of organic and conventional cropping systems in an extreme climate year. Am J Altern Agric 18:146-154. doi:10.1079 /AJAA200345 
Mäder P, Fliessbach A, Dubois D, Gunst L, Fried P, Niggli U (2002) Soil fertility and biodiversity in organic farming. Science 296:1694-1697. doi:10.1126/science.1071148

Mahoney PR, Olson KD, Porter PM, Huggins DR, Perillo CA, Crookston RK (2007) Profitability of organic cropping systems in southwestern Minnesota. Renew Agric Food Syst 19: 35-46. doi:10.1079/RAFS200361

Marriott EE, Wander MM (2006) Total and labile soil organic matter in organic and conventional farming systems. Soil Sci Soc Am J 70:950-959. doi:10.2136/sssaj2005.0241

Mbow C, Smith P, Skole D, Duguma L, Bustamante M (2014) Achieving mitigation and adaptation to climate change through sustainable agroforestry practices in Africa. Curr Opin Environ Sustain 6:8-14. doi:10.1016/j. cosust.2013.09.002

McBride W, Greene C, Foreman L, Ali M (2015) The profit potential of certified organic field crop production. USDA Economic Research Service, Washington, D.C.

MEA (2005) Millennium ecosystem assessment. World Resources Institute, Washington, D.C.

Meier MS, Stoessel F, Jungbluth N, Juraske R, Schader C, Stolze M (2015) Environmental impacts of organic and conventional agricultural products - are the differences captured by life cycle assessment? J Environ Manag 149:193-208. doi:10.1016/j.jenvman.2014.10.006

Minnich J, Hunt M (1979) The Rodale guide to composting. Rodale Press, Emmaus

Mulder C, Zwart D, Van Wijnen H, Schouten A, Breure A (2003) Observational and simulated evidence of ecological shifts within the soil nematode community of agroecosystems under conventional and organic farming. Funct Ecol 17:516525. doi:10.1046/j.1365-2435.2003.00755.x

National Research Council (1989) Investing in research: a proposal to strengthen the agricultural, food, and environmental system. National Academies Press, Washington, D.C.

Nicolay GL, Fliessbach A (2012) Production of innovations within farmer-researcher associations applying transdisciplinary research principles. Organic Eprints. http://orgprints.org/ 21768/. Accessed $20 \mathrm{Jul}$

Niggli U (2008) Current situation in organic agriculture. In: Niggli U, Slabe A, Halberg N, Schmid O, Schlüter M (eds) Vision for an organic food and farming research agenda to 2025 . IFOAM-Organics International EU Group and FiBL, Brussels, pp 11-14

Niggli U (2015) Sustainability of organic food production: challenges and innovations. Proc Nutr Soc 74:83-88. doi:10.1017/S0029665114001438

Niggli U, Willer H, Baker BP (2016) A global vision and strategy for organic farming research. TIPI-Technology Innovation Platform of IFOAM - Organics International, Research Institute of Organic Agriculture (FiBL), Frick

Niggli U, Andres C, Willer H, Baker BP (2017) A global vision and strategy for organic farming research - condensed version. TIPI-Technology Innovation Platform of IFOAMOrganics International, Research Institute of Organic Agriculture (FiBL), Frick

Norgaard RB (2009) Ecosystem services: from eye-opening metaphor to complexity blinder. Ecol Econ 69:1219-1227. doi:10.1016/j.ecolecon.2009.11.009

Nyantakyi-Frimpong H, Kangmennaang J, Bezner Kerr R, Luginaah I, Dakishoni L, Lupafya E, Shumba L, Katundu
M (2016) Agroecology and healthy food systems in semihumid tropical Africa: participatory research with vulnerable farming households in Malawi. Acta Trop. doi:10.1016/j. actatropica.2016.10.022

OECD (2015) OECD review of agricultural policies: Switzerland 2015. OECD Publishing, Paris

OK-Net Arable (2017) OK-net arable- exchange knowledge, enhance organic farming. OK-Net Arable. http://farmknowledge.org/, http://www.ok-net-arable. eu/index.php. Accessed 20 Jul 2017

Organic Research (2017) Organic Research: gateway to organic farming research information http://www.organic-research. net. Accessed 20 Jul 2017

Pardey PG, Alston JM, Chan-Kang C (2013) Public agricultural R\&D over the past half century: an emerging new world order. Agric Econ 44:103-113. doi:10.1111/agec.12055

Pardey PG, Chan-Kang C, Dehmer SP, Beddow JM (2016) Agricultural R\&D is on the move. Nature 537:301-303. doi:10.1038/537301a

Peters S (1979) Organic farmers celebrate organic research: a sociology of popular science. In: Nowotny H, Rose H (eds) Counter-movements in the sciences. Springer, Netherlands, pp 251-275

Pfiffner L, Merkelbach L, Luka H (2003) Do sown wildflower strips enhance the parasitism of lepidopteron pests in cabbage crops? Int Organ Biol Integr Control Noxious Anim Plants West Palaearctic Region Sect Bull 26:111-116

Pimentel D, Hepperly P, Hanson J, Douds D, Seidel R (2005) Environmental, energetic, and economic comparisons of organic and conventional farming systems. Bioscience 55:573582. doi:10.1641/0006-3568(2005)055[0573:EEAECO]2.0. $\mathrm{CO} ; 2$

Ponisio LC, M'Gonigle LK, Mace KC, Palomino J, de Valpine P, Kremen C (2015) Diversification practices reduce organic to conventional yield gap. Proc R Soc B Biol Sci 282. doi:10.1098/rspb.2014.1396

Practical Farmers of Iowa (2017) Practical farmers of Iowa. http://practicalfarmers.org. Accessed 20 Jul 2017

Pretty JN (1994) Alternative systems of inquiry for a sustainable agriculture. IDS Bull 25:37-49. doi:10.1111/j.17595436.1994.mp25002004.x

Pretty J, Brett C, Gee D, Hine R, Mason C, Morison J, Rayment M, Van Der Bijl G, Dobbs T (2001) Policy challenges and priorities for internalizing the externalities of modern agriculture. J Environ Plan Manag 44:263-283

Pulleman M, Jongmans A, Marinissen J, Bouma J (2003) Effects of organic versus conventional arable farming on soil structure and organic matter dynamics in a marine loam in the Netherlands. Soil Use Manag 19:157-165. doi:10.1111 /j.1475-2743.2003.tb00297.x

Rahmann G (2011) Biodiversity and organic farming: what do we know? Appl Agric For Res 61:189-208

Rahmann G, Oppermann R, Paulsen HM, Weibmann F (2009) Good, but not good enough? Research and development needs in organic farming. Landbauforschung Volkenrode 59:29-40

Reganold JP, Wachter JM (2016) Organic agriculture in the twenty-first century. Nat Plants 2:15221. doi:10.1038 /nplants.2015.221 
Reganold JP, Elliot LF, Unger YL (1987) Long-term effects of organic and conventional farming on soil erosion. Nature 330:370-372. doi:10.1038/330370a0

Reganold JP, Palmer AS, Lockhart JC, Macgregor AN (1993) Soil quality and financial performance of biodynamic and conventional farms in New Zealand. Science 260:344-349. doi:10.1126/science.260.5106.344

Reganold JP, Glover JD, Andrews PK, Hinman HR (2001) Sustainability of three apple production systems. Nature 410:926-930. doi: 10.1038/35073574

Robinson RA (1996) Return to resistance. Ag Access, Davis

Rodale JI (1961) How to grow vegetables and fruit by the organic method. Rodale Press, Emmaus

Rodale JI (1978) Encyclopedia of organic gardening. Rodale Press, Emmaus

Rosset PM, Machín Sosa B, Roque Jaime AM, Ávila Lozano DR (2011) The Campesino-to-Campesino agroecology movement of ANAP in Cuba: social process methodology in the construction of sustainable peasant agriculture and food sovereignty. J Peasant Stud 38:161-191. doi:10.1080 /03066150.2010.538584

Rundlöf M, Nilsson H, Smith HG (2008) Interacting effects of farming practice and landscape context on bumble bees. Biol Conserv 141:417-426. doi:10.1016/j.biocon.2007.10.011

Ruttan VW (1980) Bureaucratic productivity: the case of agricultural research. Public Choice 35:529-547. doi:10.1007 /bf00140084

Ruttan VW, Hayami Y (1973) Technology transfer and agricultural development. Technol Cult 14:119-151. doi:10.2307 13102398

Schader C, Stolze M, Gattinger A (2012) Environmental performance of organic farming. In: Boye JI, Arcand Y (eds) Green technologies in food production and processing. Boston, Springer US, pp 183-210. doi:10.1007/978-1-4614-158798

Schader C, Lampkin N, Christie M, Nemecek T, Gaillard G, Stolze M (2013) Evaluation of cost-effectiveness of organic farming support as an agri-environmental measure at Swiss agricultural sector level. Land Use Policy 31:196-208. doi:10.1016 /j.landusepol.2012.06.014

Schader C, Grenz J, Meier MS, Stolze M (2014) Scope and precision of sustainability assessment approaches to food systems. Ecol Soc 19:42. doi:10.5751/ES-06866-190342

Schonbeck M, Jerkins D, Ory J (2016) Taking stock: analyzing and reporting organic research investments, 2002-2014. Organic Farming Research Foundation, Santa Cruz

Seufert V, Ramankutty N (2017) Many shades of gray-the context-dependent performance of organic agriculture. Sci Adv 3:e1602638. doi:10.1126/sciadv.1602638

Seufert V, Ramankutty N, Foley JA (2012) Comparing the yields of organic and conventional agriculture. Nature 485:229232. doi:10.1038/nature 11069

Siegrist S, Schaub D, Pfiffner L, Mäder P (1998) Does organic agriculture reduce soil erodibility? The results of a long-term field study on loess in Switzerland. Agric Ecosyst Environ 69:253-264. doi:10.1016/S0167-8809(98)00113-3

Skinner C, Gattinger A, Muller A, Mäder P, Flie $\beta$ bach A, Stolze M, Ruser R, Niggli U (2014) Greenhouse gas fluxes from agricultural soils under organic and non-organic management - a global meta-analysis. Sci Total Environ 468-469: 553-563. doi:10.1016/j.scitotenv.2013.08.098
Smith-Spangler C, Brandeau ML, Hunter GE, Bavinger JC, Pearson M, Eschbach PJ, Sundaram V, Liu H, Schirmer P, Stave C, Olkin I, Bravata DM (2012) Are organic foods safer or healthier than conventional alternatives? A systematic review. Ann Intern Med 157:348-366. doi:10.7326/00034819-157-5-201209040-00007

SOAAN (2013) Best practice guideline for agriculture and value chains. Sustainable Organic Agriculture Action Network. http://wwwifoambio/en/organic-landmarks/best-practiceguideline-agriculture-and-value-chains. Accessed 20 July

Średnicka-Tober D, Barański M, Seal C, Sanderson R, Benbrook C, Steinshamn H, Gromadzka-Ostrowska J, Rembiałkowska E, Skwarło-Sońta K, Eyre M, Cozzi G, Krogh Larsen M, Jordon T, Niggli U, Sakowski T, Calder PC, Burdge GC, Sotiraki S, Stefanakis A, Yolcu H, Stergiadis S, Chatzidimitriou E, Butler G, Stewart G, Leifert C (2016a) Composition differences between organic and conventional meat: a systematic literature review and meta-analysis. Br J Nutr 115:994-1011. doi:10.1017/S0007114515005073

Średnicka-Tober D, Barański M, Seal CJ, Sanderson R, Benbrook C, Steinshamn H, Gromadzka-Ostrowska J, Rembiałkowska E, Skwarło-Sońta K, Eyre M, Cozzi G, Larsen MK, Jordon T, Niggli U, Sakowski T, Calder PC, Burdge GC, Sotiraki S, Stefanakis A, Stergiadis S, Yolcu H, Chatzidimitriou E, Butler G, Stewart G, Leifert C (2016b) Higher PUFA and n-3 PUFA, conjugated linoleic acid, $\alpha$-tocopherol and iron, but lower iodine and selenium concentrations in organic milk: a systematic literature review and meta- and redundancy analyses. Br J Nutr 115:1043-1060. doi:10.1017 /S0007114516000349

Stolze M, Piorr A, Häring A, Dabbert S (2000) The environmental impact of organic farming in Europe. Organic farming in Europe: economics and policy, Vol 6. Hago Druck \& Medien, Karlsbad-Ittersbach

TEEB (2010) The economics of ecosystems and biodiversity ecological and economic foundations. Earthscan, London

The Organic Research Centre (2017) ORC's Farmers' Organic Research Club (FORC). http://www.organicresearchcentre. $\mathrm{com} /$ ? go $=$ research $\% 20$ and $\% 20$ development $\&$ page $=$ Farmers\%92\%20Organic\%20Research\%20Club. Accessed 14 Jul 2017

Tittonell P (2014) Ecological intensification of agriculture- sustainable by nature. Curr Opin Environ Sustain 8:53-61. doi:10.1016/j.cosust.2014.08.006

Tuck SL, Winqvist C, Mota F, Ahnstrom J, Turnbull LA, Bengtsson J (2014) Land-use intensity and the effects of organic farming on biodiversity: a hierarchical meta-analysis. J App1 Ecol 51:746-755. doi:10.1111/1365-2664.12219

UN (2017) Sustainable Development Goals. https://sustainabledevelopment.un.org/?menu=1300. Accessed 20 Jul 2017

van Bueren ETL, Jones SS, Tamm L, Murphy KM, Myers JR, Leifert C, Messmer MM (2011) The need to breed crop varieties suitable for organic farming, using wheat, tomato and broccoli as examples: a review. NJAS-Wageningen J Life Sci 58:193-205. doi:10.1016/j.njas.2010.04.001

van der Laan M, Bristow K, Stirzaker R, Annandale J (2017) Towards ecologically sustainable crop production: a south African perspective. Agric Ecosyst Environ 236:108-119. doi:10.1016/j.agee.2016.11.014 
Vandermeer J, Perfecto I, Philpott S (2010) Ecological complexity and pest control in organic coffee production: uncovering an autonomous ecosystem service. Biosciences 60:527-537. doi:10.1525/bio.2010.60.7.8

Vanloqueren G, Baret PV (2009) How agricultural research systems shape a technological regime that develops genetic engineering but locks out agroecological innovations. Pes Policy 38:971-983. doi:10.1016/j.respol.2009.02.008

Verhoog H (2007) Organic agriculture versus genetic engineering. NJAS- Wageningen J Life Sci 54:387-400. doi:10.1016 /S1573-5214(07)80011-X

Walkenhorst M, Heil F, Ivemeyer S, Klocke P, Mäschli A, Notz C (2006) Focussing on health promotion on organic farming in practice - the example of the Swiss pro-q project. Organic Eprints. http://orgprintsorg/7684/. Accessed $20 \mathrm{Jul}$

Weltzien E, Smith ME, Meitzner LS, Sperling L (2003) Technical and institutional issues in participatory plant breeding-from the perspective of formal plant breeding: a global analysis of issues, results, and current experience. CGIAR Systemwide Program on Participatory Research and Gender Analysis for Technology Development and Institutional Innovation, CIAT, Cali

Wickramasinghe LP, Harris S, Jones G, Vaughan N (2003) Bat activity and species richness on organic and conventional farms: impact of agricultural intensification. J Appl Ecol 40:984-993. doi:10.1111/j.1365-2664.2003.00856.x

Willer H, Lernoud J (2016) The world of organic agriculture. Statistics and emerging trends 2016. Research Institute of Organic Agriculture (FiBL), Frick and IFOAM-Organics International, Bonn

Willer H, Lernoud J (2017) The world of organic agriculture. Statistics and emerging trends 2017. Research Institute of Organic Agriculture (FiBL), Frick and IFOAM-Organics International, Bonn

Wilson JD, Evans J, Browne SJ, King JR (1997) Territory distribution and breeding success of skylarks Alauda arvensis on organic and intensive farmland in southern England. J Appl Ecol 34:1462-1478. doi:10.2307/2405262

Wynen E, Mitchell A (2013) Organic farming in Australia. In: Willer H, Lernoud J, Kilcher L (eds) The world of organic agriculture. Statistics and emerging trends 2013 | FiBLIFOAM report. Research Institute of Organic Agriculture (FiBL), Frick, and International Federation of Organic Agriculture Movements (IFOAM), Bonn

Youngberg G (1980) Report and recommendations on organic farming. USDA, Washington, D.C.

Youngberg G, DeMuth SP (2013) Organic agriculture in the United States: a 30-year retrospective. Renew Agric Food Syst 28:294-328. doi:10.1017/S1742170513000173 